\title{
バセドウ病患者の甲状腺体積 : 抗甲状腺剤治療中の変化および予後との関係
}

\author{
大阪医科大学第一内科 \\ （主任：大澤仲昭教授） \\ 坂 根 貞 樹
}

\section{The Prognostic Application of Thyroid Volume Determination in Patients with Graves' Disease}

\section{Sadaki SAKANE}

The First Department of Internal Medicine,

Osaka Medical College, Takatsuki, Japan

(Director: Professor Nakaaki Ohsawa, M.D.)

Swelling of the thyroid gland is a common symptom in patients with Graves' disease. However, until recently there were no adequate means of measuring the thyroid volume. In this study, thyroid volume (in Graves' disease patients on antithyroid drug (ATD) therapy) was measured serially by a new ultrasound technique involving the use of a specifically programmed computer. The relationships between thyroid volume and prognosis, and between thyroid volume and serum thyroglobulin $(\mathrm{Tg})$ concentration were examined.

Sixty untreated patients with Graves' disease and 62 healthy subjects were included in the study. Twenty of the 60 patients with Graves' disease who had no anti-Tg antibodies underwent serial measurement of thyroid volume and serum $\mathrm{Tg}$ concentration during long term (18 42 months) ATD therapy .

Thyroid volume in normal subjects ranged from $5.6 \mathrm{ml}$ to $20.2 \mathrm{ml}$, with a mean of $12.0 \pm 4.0 \mathrm{ml}$. In patients with untreated Graves' disease, the volume ranged from 13.3 to $190.7 \mathrm{ml}$ with a mean of $40.2 \pm 27.8 \mathrm{ml}(\mathrm{n}=60)$. Thyroid volume was significantly correlated with both serum $\mathrm{Tg}$ concentration $(\mathrm{n}=20, \mathrm{r}=0.678, \mathrm{p}<0.01)$ and serum TSH receptor antibody activity $(n=18, r=0.590, p<0.01)$. During ATD therapy, the thyroid volume decreased gradually in most patients. Eleven of 20 treated patients experienced remission after therapy was discontinued, and in these patients, thyroid volume was significantly smaller $(\mathrm{p}<0.01)$ than before treatment. Four patients developed hypothyroidism due to over dosage of ATD at which time thyroid volume increased in all four. In the course of therapy, even during episodes of hypothyroidism changes in serum $\mathrm{Tg}$ concentrations paralleled changes in thyroid volume. After 12 months of therapy, thyroid volume expressed as a percentage of the pretreatment value was significantly smaller in patients in remission 
$(77.6 \pm 8.9 \%)$ than in those who did not show remission $(92.4 \pm 11.6 \%)$.

These data suggest that serial ultrasonographic measurement of thyroid volume is useful in predicting the course of hyperthyroidism in ATD-treated patients with Graves' disease.

\section{緒言}

甲状腺疾患の多くは甲状腺の腫大を伴っている。このうちバセドゥ病では, その臨床像として古 くは Merseburg の三徵としても述べられているように, 頻脈, 眼球突出とともに甲状腺腫が重要 視されている。この疾患の病因については，1956年 Adams らによる LATS の発見 ${ }^{11}$ 以来甲状腺 を刺激する immunoglobulin が重要な因子と考えられている ${ }^{16)}$ 。また最近では甲状腺の増大を促 進する因子として thyroid growth immunoglobulin の存在を示唆する報告もなされており ${ }^{57736)}$, バセドウ病に伴な5甲状腺の腫大が，病因論的にも改めて注目されている。

甲状腺の腫大度を表現する方法として，わが国では視診と触診所見による七條分類28)や，甲状腺 の横径を用いることが多い。しかしこれらの方法では客観的なデータとして満足しうる測定精度を 得ることは困難であった。また甲状腺シンチグラムを用いた方法"3)では検査法が煩雑で繰り返し測 定しにくいこと, 甲状腺の厚さが測定值に反映されないことなどの問題点があった。これらの欠点 を補ら方法として，最近超音波による甲状腺体積の測定法が開発された ${ }^{910211233333399}$ 。著者らの施設 においても数年前から独自の方法を開発してきた ${ }^{2182(26) 32) 。 ~}$

バセドウ病患者を抗甲状腺剂で治療する場合, 治療前の甲状腺が小さい例や治療中甲状腺腫が縮 小する例が一般に寛解しやすいことが知られている6)。著者は本研究に扔いて，バセドウ病患者を 対象とし, 未治療時から内服治療中, さらに内服中止後寛解あるいは再発にいたるまでの長期間に わたり正確な甲状腺体積を経時的に測定した。その目的は内服治療中の甲状腺体積の変動がどのよ らな意義をもつかを明らかにするとともに，抗甲状腺剤治療効果および予後との関連について検討 することにある。また血中サイログロブリン $(\mathrm{Tg})$ 濃度 ${ }^{152) 25}$ も同時に測定し, 甲状腺体積との関係 についても分析した。

\section{対 象}

大阪医科大学病院第一内科を受診した未治療バセドウ病患者60名について甲状腺体積と血中 $\mathrm{Tg}$ の濃度の測定を行なった。血中抗 $\mathrm{Tg}$ 自己抗体が陰性であったのは, 60例中20例（男性7名, 女性13名, 平均年齢34.3歳) であった。これら20例を抗甲状腺剤治療中, 長期間観察する対象例と した。また健常者62名（男性30名，女性32名，平均年齢37.6歳）についても検討した。

方法

\section{1. 甲状腺体積の測定}

甲状腺体積は著者らの教室にて開発した電算機化超音波法 ${ }^{1820032}$ により測定した。Water bag を 用いて, 被検者の体横断面に平行に設置したプローブを毎秒 $1 \mathrm{~cm}$ の速度で自動に走査させ, 128 枚 の連続する甲状腺横断断層像を得た。この断層像をコンピューターに入力し, 軸変換処理を行って 64枚の前額断層像拉よび64枚の矢状断層像を構成した。Fig.1亿示すよ5に前額断層像の中から左 
右両葉の最大前額断面積を求め, 右葉を $\mathrm{AR}$ ，左葉を $\mathrm{AL}$ とした。甲状腺の峡部が腫大してい る例では，その前額断面積を2分割して左右両葉に含めて計測した。同様に矢状断層像から，最大 の厚さ TR (右葉), TL（左葉）を求め, 以下の式より甲状腺体積を算出した。甲状腺体積= $\kappa \times(\mathrm{AR} \times \mathrm{TR}+\mathrm{AL} \times \mathrm{TL})$ 定数 $\kappa$ を求めるため, 甲状腺严全摘術をうけたバセドウ病患者 19 例に ついて, 手術時に求めた甲状腺体積の実測值と, 術前に測定した甲状腺体積のデータから回帰式を 求め, $\kappa=0.766$ が得られた。なお両者間の相関係数は $\mathrm{r}=0.954$ と良好であった。測定精度に関し ては，同一検者が同一患者を反復測定したときの測定間䛊差の変動係数 $(\mathrm{CV})$ は平均 $8.6 \%$ であっ た。また異なる検者が測定したとき $\mathrm{CV}$ は $8.8 \%$ であり，満足しうる再現性を示した。

\section{2. 抗甲状腺剂治療}

治療には methimazole（商品名メルカゾール）を用いて1日量30mg を分割投与した。血中甲状 腺ホルモン濃度が正常域にまで低下した後，1日投与量を5 10mg ずつ減量し，最終的に 1 日 $5 \mathrm{mg}$ あるいは隔日 $5 \mathrm{mg}$ の投与量に維持した。維持量のメルカゾール投与中に血中 TSH 濃度が正常範 囲となり，血中 TSH レセプタ一抗体価が陰性化した時期に，メルカゾール投与を中止した。治 療開始後24か月以内に治療を中止し，その後6か月以上甲状腺機能立進症の再発をきたさない患者 を寬解例と判定した。また抗甲状腺剂過剩投与によって機能低下症になった例では，その時点で投 薬を減量ないし中止し, 経過を観察した。24か月以内に投与を中止した例は20例中14例で, 機能低 下症例を 4 例，投与中止後再発した例を3例を含んでいる。寛解を得られた症例は11例であり，寛解 例におけるメルカゾールの投与期間は6か月から $24 か$ 月, 平均 15.7 月であった。非寛解例を含め た各症例の経過追跡期間は 18 月から 42 かてであり，平均 24 月であった。

\section{3. 血中 $\mathrm{Tg}$ 濃度および TSH レセプター抗体価の測定}

血中 $\mathrm{Tg}$ 濃度測定には栄研イムノケミカル社の RIA キット党を用いた。このキットの第一法で ある抗 $\mathrm{Tg}$ 自己抗体 RIA 測定值が $15 \%$ 以下の例についてのみ, 血中 $\mathrm{Tg}$ 濃度測定が可能と判定 した。血中 $\mathrm{Tg}$ 濃度が $160 \mathrm{ng} / \mathrm{ml}$ 以上を示した症例では, 被検血清に $\mathrm{Tg}$ を含まない血清（栄研

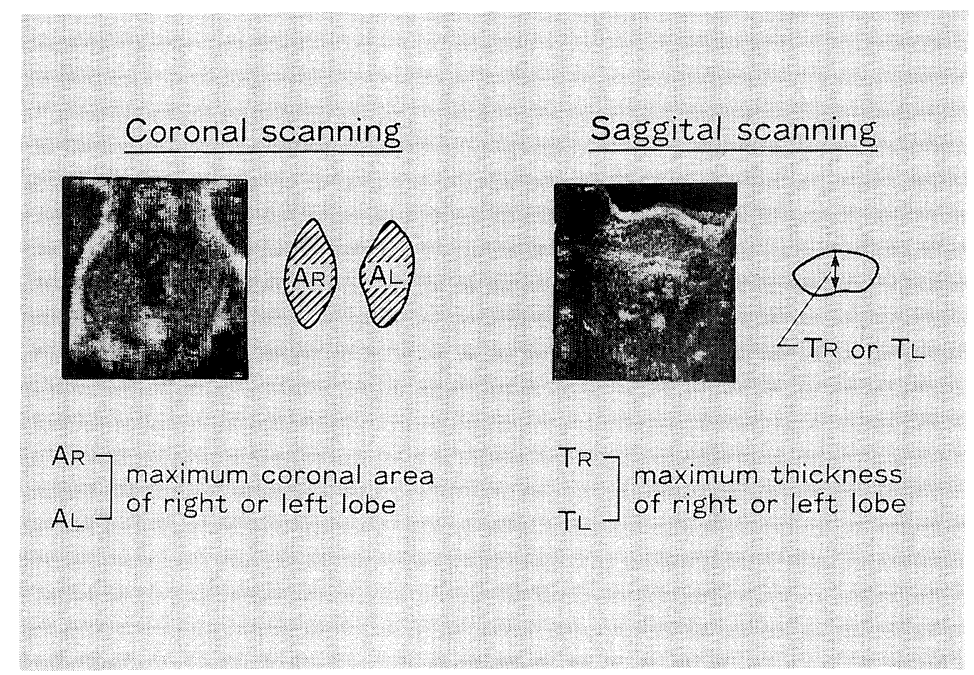

Fig. 1. Pictures of ultrasonography of the thyroid gland: maximal coronal area and maximal thickness was measured from the picture. 
から供与）を加えて希釈し，再測定して濃度を求めた。血中 TSH レセプター抗体活性（TRAb） は Rees Smith のラジオレセプターアッセイキット ${ }^{27}$ で測定した。

各群のデータは mean $\pm \mathrm{SD}$ にて表現した。有意差検定は Student's t-test によった。

結

果

\section{1. 健常者および未治療バセドウ病患者の甲状腺体積}

健常者 62 名における甲状腺体積は $5.6 \mathrm{ml}$ から $20.2 \mathrm{ml}$ に分布し，平均 $12.0 \pm 4.0 \mathrm{ml}$ であった。 Fig.2-A に示すよ5に，未治療バセドウ病患者60例の甲状腺体積は $13.3 \mathrm{ml}$ から $190.7 \mathrm{ml}$ に分布 し, 平均 $40.2 \pm 27.8 \mathrm{ml}$ であった。健常者のデータの mean $\pm 2 \mathrm{SD}$ を正常範团と定めると，60例 中57例（95\%）において甲状腺体積が正常範囲以上に腫大していた。

Table 1に対象とした抗 $\mathrm{Tg}$ 自己抗体陰性患者20名について，未治療時甲状腺機能検査成績を甲 状腺体積の大きいものから順に列記した。これらの症例の血中 Tg 濃度は，Fig.2-B に示すよう に, $44 \mathrm{ng} / \mathrm{ml}$ から $620 \mathrm{ng} / \mathrm{ml}$ に分布し平均 $210 \pm 152 \mathrm{ng} / \mathrm{ml}$ であった。また血中 TRAb は測定し た18例において $12.7 \%$ 72.5\%に分布し平均 $41.2 \pm 20.0 \%$ と高值を示した。

Fig.3 に示すように, 治療前の血中 $\mathrm{Tg}$ 濃度と甲状腺体積の閒には $\mathrm{r}=0.678(\mathrm{P}<0.01)$ の有 意な相関関係が認められた。TRAb と甲状腺体積との間にも $\mathrm{r}=0.590 \quad(\mathrm{P}<0.01)$ の有意の相関 関係があった。これに対して TRAb と血中 Tg 濃度との相関係数は $\mathrm{r}=0.422$ であり，成績は示 さなかったが，統計上有意ではなかった。

A

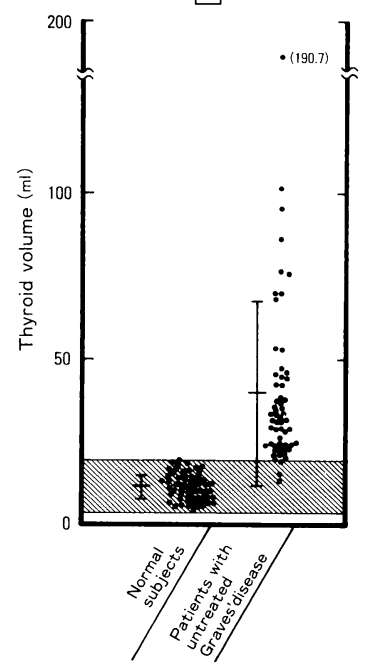

B

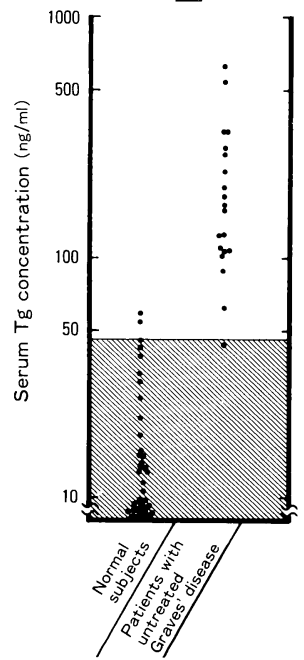

Fig. 2. Thyroid volume and serum thyroglobulin ( $\mathrm{Tg}$ ) concentrations in normal subjects and patients with untreated Graves' disease. The shaded area represents normal ranges. 
Table 1. Initial data of thyroid function in patients with Graves' disease with no anti-thyroglobulin antibodies.

\begin{tabular}{|c|c|c|c|c|c|c|c|c|c|}
\hline \multirow[b]{2}{*}{ CASE } & \multirow{2}{*}{$\begin{array}{l}\text { AGE } \\
\& \\
\text { SEX }\end{array}$} & \multicolumn{7}{|c|}{ SERUM LEVELS } & \multirow{2}{*}{$\begin{array}{l}\text { Thyroid } \\
\text { volume }\end{array}$} \\
\hline & & $\begin{array}{c}\mathrm{T}_{4} \\
(\mu \mathrm{g} / \mathrm{dl})\end{array}$ & $\begin{array}{c}\mathrm{T}_{3} \\
\text { (ng/dl) }\end{array}$ & $\begin{array}{c}\mathrm{T}_{3} / \mathrm{T}_{4} \text { ratio } \\
\left(\mathrm{ng} / \mu_{\mathrm{g}}\right)\end{array}$ & $\begin{array}{c}\text { TGHA/MCHA } \\
\text { (titer) }\end{array}$ & $\begin{array}{c}\text { anti-Tg Ab } \\
(\%)\end{array}$ & $\begin{array}{c}\mathrm{Tg} \\
(\mathrm{ng} / \mathrm{ml})\end{array}$ & $\begin{array}{c}\text { TRAb } \\
(\%)\end{array}$ & \\
\hline 1. & $30 \mathrm{~F}$ & 37.8 & 725 & 19.2 & neg $/ 320^{2}$ & 8.4 & 290 & 61.0 & 95.3 \\
\hline 2. & $45 M$ & 32.0 & 639 & 20.0 & $\mathrm{neg} / 5120^{2}$ & 8.4 & 530 & 59.8 & 84.3 \\
\hline 3. & $20 \mathrm{~F}$ & 30.4 & 695 & 22.9 & neg $/ 40^{2}$ & 13.0 & 275 & 70.6 & 65.6 \\
\hline 4. & $25 \mathrm{~F}$ & 21.5 & 800 & 37.2 & $\mathrm{neg} / 2560^{2}$ & 9.8 & 620 & 43.4 & 60.2 \\
\hline 5. & $45 \mathrm{~F}$ & 16.3 & 334 & 20.5 & $\mathrm{neg} / 20^{2}$ & 8.3 & 231 & 45.6 & 53.0 \\
\hline 6. & $18 \mathrm{M}$ & 30.9 & 535 & 17.3 & neg $/ 80^{2}$ & 11.0 & 197 & 55.0 & 48.5 \\
\hline 7. & $39 M$ & 24.8 & 466 & 14.7 & $n e g / 20^{2}$ & 9.8 & 126 & 31.3 & 42.5 \\
\hline 8. & $43 \mathrm{~F}$ & 25.4 & 474 & 18.7 & neg $/ 10^{2}$ & 9.5 & 340 & 72.5 & 42.1 \\
\hline 9. & $39 \mathrm{~F}$ & 15.3 & 241 & 15.7 & neg $/ 40^{2}$ & 9.0 & 111 & - & 29.1 \\
\hline 10. & $45 \mathrm{M}$ & 16.3 & 354 & 21.7 & neg $/ 80^{2}$ & 10.0 & 160 & - & 27.0 \\
\hline 11. & $27 \mathrm{~F}$ & 16.1 & 251 & 15.6 & neg/neg & 9.2 & 168 & 24.3 & 26.4 \\
\hline 12. & $25 \mathrm{M}$ & 14.3 & 232 & 16.2 & $n e g / 20^{2}$ & 11.8 & 62 & 14.3 & 24.1 \\
\hline 13. & $44 \mathrm{~F}$ & 19.2 & 454 & 23.6 & neg $/ 20^{2}$ & 8.4 & 89 & 23.1 & 23.0 \\
\hline 14. & $19 M$ & 13.7 & 244 & 17.8 & neg $/ 80^{2}$ & 13.0 & 108 & 66.5 & 22.8 \\
\hline 15. & $63 F$ & 15.6 & 313 & 20.1 & neg/neg & 9.1 & 340 & 20.3 & 22.2 \\
\hline 16. & $38 \mathrm{M}$ & 19.7 & 548 & 27.8 & neg/neg & 8.1 & 102 & 41.2 & 21.8 \\
\hline 17. & $35 \mathrm{~F}$ & 17.7 & 384 & 21.7 & $\mathrm{neg} / 320^{2}$ & 7.5 & 108 & 12.7 & 21.7 \\
\hline 18. & $44 \mathrm{~F}$ & 17.4 & 355 & 20.4 & $\mathrm{neg} / 20^{2}$ & 9.8 & 124 & 20.4 & 20.3 \\
\hline 19. & $20 \mathrm{~F}$ & 18.7 & 360 & 19.3 & neg/neg & 9.2 & 180 & 52.4 & 19.9 \\
\hline 20. & $22 \mathrm{~F}$ & 19.2 & 351 & 18.3 & neg/neg & 8.6 & 44 & 31.0 & 15.8 \\
\hline
\end{tabular}

A

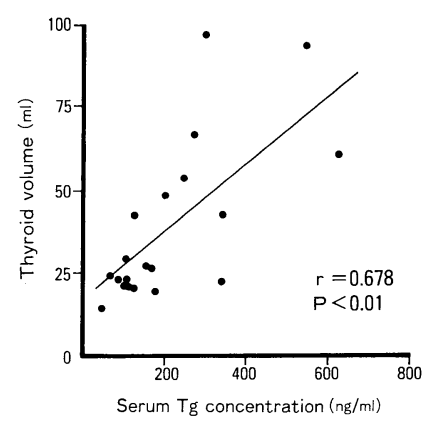

B

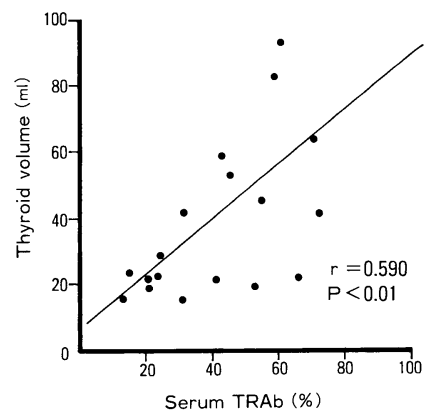

Fig. 3. Correlations between thyroid volume and serum Tg concentrations $[\mathrm{A}]$ and serum TSH receptor antibodies (TRAb) activities $[B]$ in patients with untreated Graves' disease.

\section{2. 症例呈示}

Fig.4に，対象20例のなかから2例を選び甲状腺体積の治療中の変動を示した。Fig.4-A に示し た CASE17は35歳女性で, 主訴は動悸。初診時血中 T4濃度は $17.7 \mu \mathrm{g} / \mathrm{dl}, \mathrm{Tg}$ 濃度は $108 \mathrm{ng} / \mathrm{ml}$, $\mathrm{TRAb}$ は $12.7 \%$ であり, 甲状腺体積は $21.7 \mathrm{ml}$ であった。内服治療 2 か月後, 血中 $\mathrm{T} 448.7 \mu \mathrm{g} / \mathrm{dl}$ と低下し, メルカゾールの投与量を漸減した。18か月後内服を中止しそれ以後12か月間, 現在まで 甲状腺機能元進症の再燃は来たしていない。甲状腺体積および血中 $\mathrm{Tg}$ 濃度は内服6か月後それぞ れ $20.5 \mathrm{ml}, 42 \mathrm{ng} / \mathrm{ml}$ と減少し, 内服中止時には $12.4 \mathrm{ml}, 39 \mathrm{ng} / \mathrm{ml}$ と正常範囲の值となり，その 後明かな上昇は示さなかった。

Fig.4-B は CASE16で38歳男性。体重減少を主訴とし, 血中 T4濃度 $19.7 \mu \mathrm{g} / \mathrm{dl}, \mathrm{Tg}$ 濃度 $102 \mathrm{ng} / \mathrm{ml}$, TRAB $41.2 \%$, 甲状腺体積は $21.8 \mathrm{ml}$ であった。メルカゾール内服後, 血中甲状腺ホ 
ルモン濃度は正常範团からさらに低值となり, 血中 $\mathrm{TSH}$ 濃度が50 $\mu \mathrm{U} / \mathrm{ml}$ 一と上昇した。甲状 腺体積はこのとき $34.6 \mathrm{ml}$ へと増加し, 血中 $\mathrm{Tg}$ 濃度も $174 \mathrm{ng} / \mathrm{ml}$ と上昇した。その後内服量を減 量し甲状腺機能を正常にコントロールしたところ, 甲状腺体積と血中 $\mathrm{Tg}$ 濃度はともに減少した。 22か月間の内服後服薬を中止し, その後寛解状態が続いている。

\section{3. 治療中の甲状腺体積および血中 $\mathrm{Tg}$ 濃度の変化}

対象20例における甲状腺体積の変化を Fig.5に示した。抗甲状腺剂治療によって甲状腺体積が徐々 に減少した例が多かった。抗甲状腺剤を中止した13例の5ち，6例では中止時に甲状腺体積が正常 範囲にまで減少した。一方, 内服中甲状腺が増大する例がみられ, CASE 6, 8, 12, 16 の上 らに一過性に機能低下状態となり血中 TSH が上昇したときに体積の増大が観察された（図で は …………- で表示)。また CASE13では抗甲状腺剤投与中止後, 機能京進症の再発した経過に おいても甲状腺体積が増加した（図では--D---ーで表示）。治療前に甲状腺腫大が特に著しい CASE 1，2，3 では明かな体積の減少が認められなかった。

Fig.6では治療中, 一過性に甲状腺機能が低下し, 血中 TSH が $20 \mu \mathrm{U} / \mathrm{ml}$ 以上に上昇した患者 4例について, 機能立進, 機能正常, 機能低下の各時期に抢いての甲状腺体積 (A), 血中 $\mathrm{Tg}$ 濃 度（B）および血中 TRAb 值 (C) を比較した。機能低下時には甲状腺体積, 血中 $\mathrm{Tg}$ 濃度は全 例増加した。

A
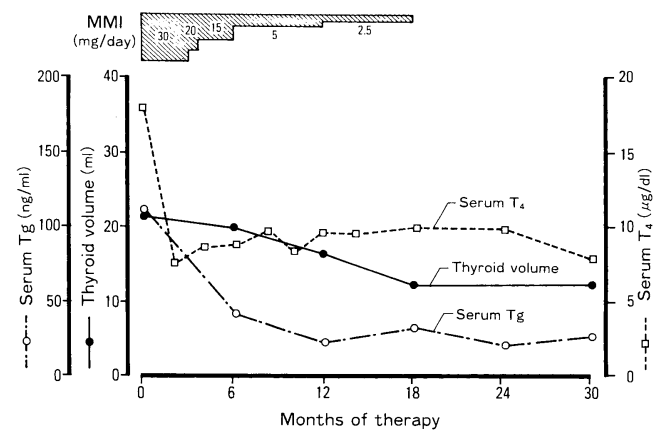

B

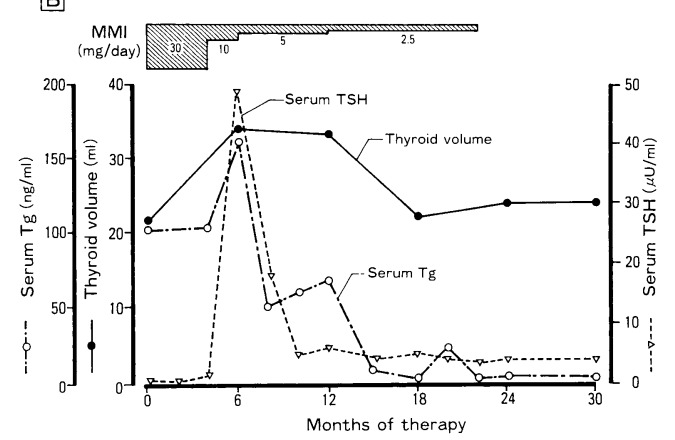

Fig. 4. Clinical course of examples of two patients with Graves' disease during antithyroid drug therapy. Case 18 is shown in figure $[\mathrm{A}]$ and Case 17 in figure $[B]$. 
Fig.7に治療経過中の甲状腺体積の変動と血中 $\mathrm{Tg}$ 濃度の変動との関係を図示した。すなわち横 軸に血中 $\mathrm{Tg}$ 濃度の増加量ないし減少量を前值に対する百分率（\%）で表現し，縦軸には甲状腺 体積の増加ないし減少（\%）をとってプロットした。総計62回の分析データのらち，両指数とも陽 性の動きをとる例が11回, ともに陰性の動きをとる37回となり, 両者を合わせると全体の $77 \%$ 占 めた。

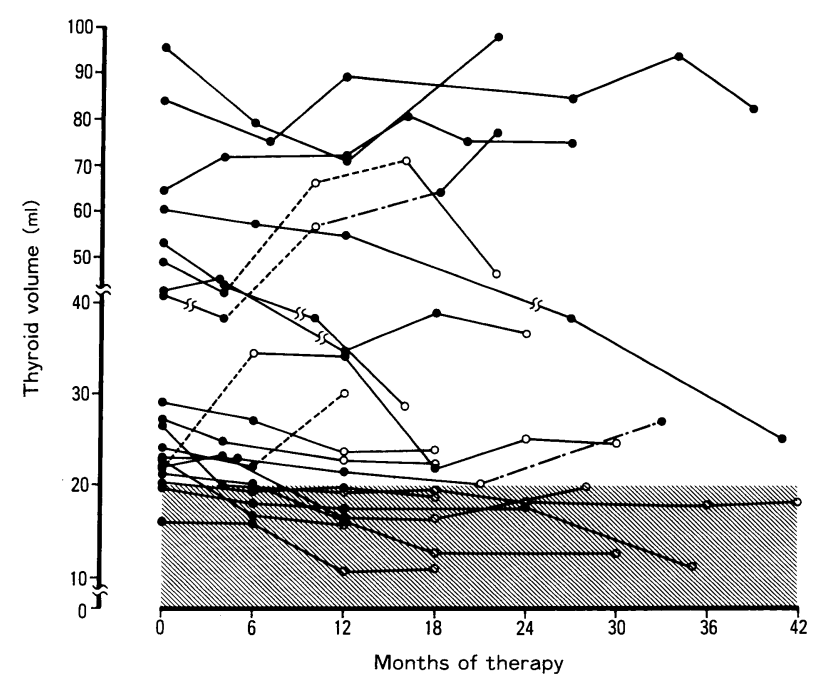

Fig. 5. Changes of thyroid volume in patients with Graves' disease during antithyroid drug therapy. [O] represents the data during therapy with antithyroid drugs. [O] represents the data while the patient was in remission after withdrawal of the drug. Lines [--.-.--] represents the data when transient hypothyroidism occurred due to overdosage of the drug. Lines [-- - ] represents the data when hyperthyroidism recurred after cessation of the drug.
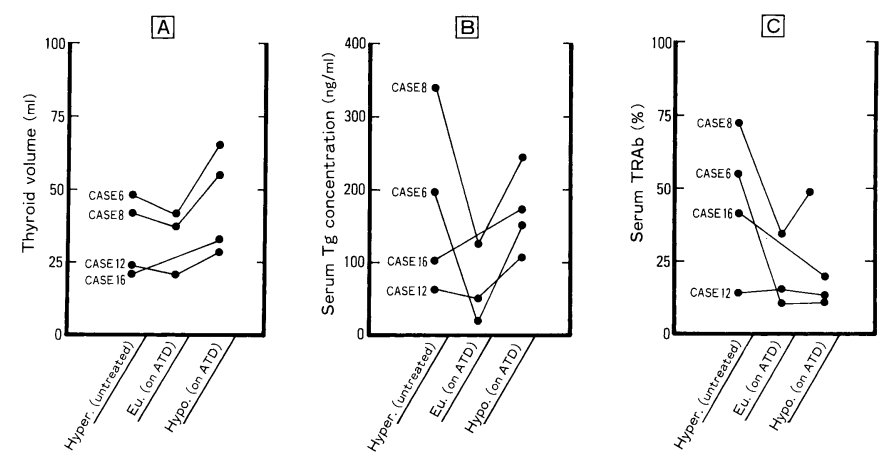

Fig. 6. Changes in thyroid volume, serum $\mathrm{Tg}$ concentrations, and serum TRAb activities in 4 patients who had transient hypothyroidism due to overdosage of antithyroid drugs. 


\section{4. 寛解例における甲状腺体積と血中 $\mathrm{Tg}$ 濃度}

対象患者20例中11例では，24か月以内に抗甲状腺剤の投与を中止し，その後甲状腺機能立進症が 再熱せず，寛解が得られた。

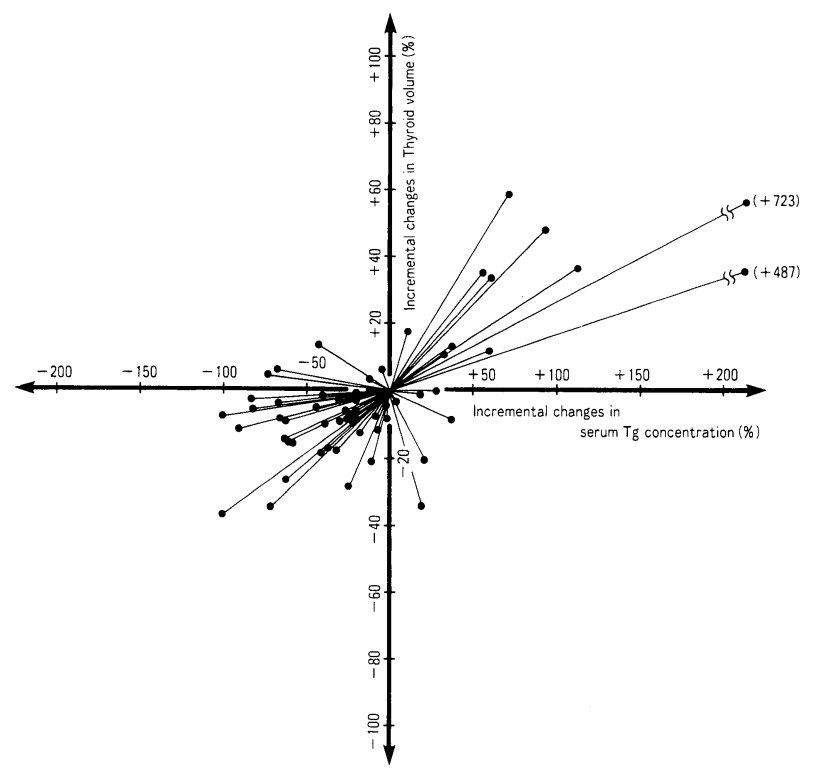

Fig. 7. Changes in thyroid volume in relation to simultaneous changes in serum $\mathrm{Tg}$ concentrations during therapy. The data were expressed as a percent increment from the pre-value.

A

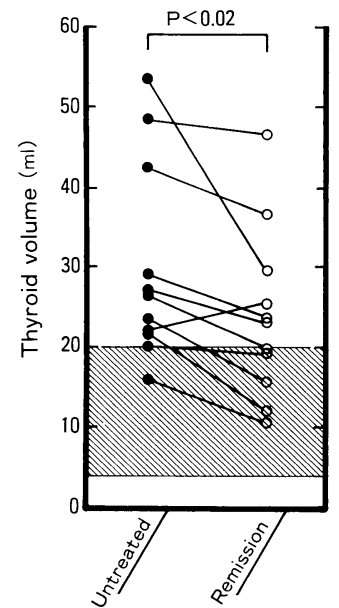

B

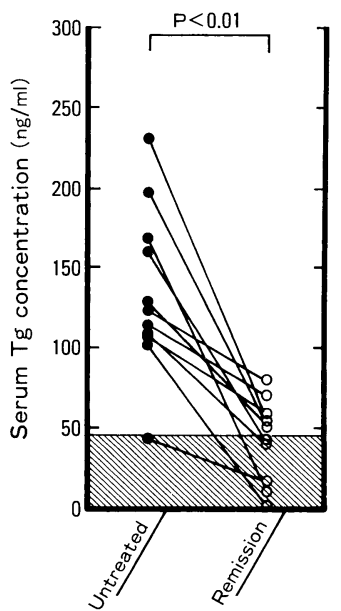

Fig. 8. Changes in thyroid volume and serum Tg concentrations from the untreated state to the remission state. 
Fig.8-A に示すように，これらの例では甲状腺体積は1例を除き全例にて減少した。しかし治療 中止時に甲状腺体積が正常範囲（20.0 ml 以下）にまで減少した例は5例にとどまり，寛解患者の 11例中6例において甲状腺体積は高值域のままであった。血中 $\mathrm{Tg}$ 濃度も $134.3 \pm 51.5 \mathrm{ng} / \mathrm{dl}$ から $43.7 \pm 25.3 \mathrm{ng} / \mathrm{ml}$ ヘと全例で明らかな減少を認めた（Fig.8-B）。

\section{5. 寛解例と非寛解例の比較}

寛解患者と，24か月以上抗甲状腺剂投与を中止できず治療を続行している非寛解患者について比 較した。治療前の甲状腺体積についての検討では， $60.0 \mathrm{ml}$ 以上の例には寛解を得られたものでは なかった。これに対して，25.0ml 以下の例でも寛解を得られないものを8例中3例認めた。未治療 時の体積を平均値で比較すると寛解群 $29.7 \pm 12.5 \mathrm{ml}$, 非寛解群 $51.6 \pm 29.3 \mathrm{ml}$ であり, 寛解群にて 低值の傾向にあったが，その差は統計学的に有意ではなかった。

次に治療中の甲状腺体積の減少率を分析した。Fig.9に未治療時の甲状腺体積を 100（\%）とし て治療後の体積を\%で表示し, 体積の変動を示した。非寛解群では甲状腺体積の減少率は少なく,

Comparison of Changes in Thyroid Volume between Patients with Remission $\mathrm{A}$ and Non-remission $\mathrm{B}$
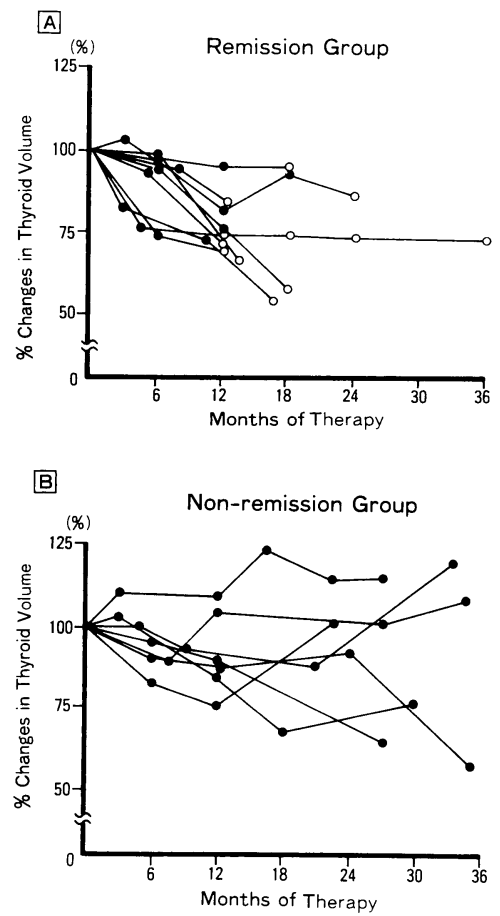

Fig. 9. Comparison of changes in thyroid volume between patients with remission $[\mathrm{A}]$ and non-remission $[B]$. The data were expressed as percentages of the pretreatment value. [O] represents the data during therapy with antithyroid drugs. [O] represents the data while the patient was in remission after withdrawal of the drug. 
むしろ増大する傾向を示す例も見られた。一過性機能低下症のため体積の增大を来たした例を除外 して, 両群の\%減少率を平均値で分析すると, 内服6か月後では寛解群が87.9土9.2\%, 非寛解群が $91.6 \pm 6.5 \%$ であった。12か月後ではそれぞ机7.6 $18.9 \% ， 92.4 \pm 11.6 \%$ であり，両群間に有意 差 $(\mathrm{P}<0.02)$ が認められた。

\section{考案}

今回甲状腺体積の測定に用いた方法は, 精度と再現性において満足しうる測定法であることが確 認された。本法は患者に負担をかけることが少ないため，経過を追って繰り返し測定でさる利点も 有している。

バセドゥ病患者のなかで，甲状腺腫大の明らかでない患者が存在することが報告されている ${ }^{12)}$ Hegedus らは超音波測定にて，未治療患者の $23 \%$ が正常範囲の甲状腺体積であると報告した ${ }^{11)}$ 。 著者のデータでは，60例中3例 $(5 \%)$ が正常範囲内の值であった。

甲状腺腫が抗甲状腺剂治療中にどの程度縮小するかについて，客観的なデータを示した報告は殆 ぞない。著者の患者では甲状腺体積は緩徐に減少する例が多かった。特に寛解を得た患者ではその 傾向は明らかであったが，寛解状態を維持している患者でも甲状腺体積が正常域まで下がらない例 も認められた。

甲状腺の大きさを規定する因子として, 病理組織学的には甲状腺濾胞上皮の增殖の程度, 滤胞内 のコロイド量, 間質結合織の増殖及びリンパ球の浸潤などがあげられる 状腺腫が縮小する機序としては，第一に増殖した濾胞上皮が偏平化するためとも報告されている ${ }^{38)}$ 。 しかしそれ以外にもリンパ球浸潤の減少やコロイド量自体の減少も関与しているものと考兄られる。 甲状腺体積減少の原因の一つとして，甲状腺刺激抗体が治療によって減少したことが考えられる。 今回宽解が得られた症例は, TRAb が陰性化するまで治療を行ない11例中10例で甲状腺体積の減 少が確認された。それ以外にも thyroid growth immunoglobulin ${ }^{4)}$ の消長も直接甲状腺体積に 影響している可能性があるので，この抗体価の変動との関係をさらに詳細に検討することが重要で あろう。

本研究では甲状腺体積と血中 Tg 濃度との関連性についても注目した。両者が相関することは 既に nontoxic goiter の患者について報告されている ${ }^{2224)}$ 。むたバセドウ病患者では，治療前の甲 状腺腫大度と血中 $\mathrm{Tg}$ 濃度との間に有意の相関関係があると報告されている ${ }^{15}$ 。ただ抗甲状腺剤 内服治療中に抢ける両者の変動の関連性については報告が少ない。今回の検討から，甲状腺体積と 血中 $\mathrm{Tg}$ 濃度は未治療時に有意の相関関係にあり, 治療経過中も平行して変動することが観察さ れた。血中 Tg 濃度も甲状腺体積と同様に甲状腺刺激物質に影響を受けると考兄られている ${ }^{13314344)}$ 。 しかしながら今回得られた治療前の TRAb 值と甲状腺体積および血中 Tg 濃度の3つの測定値間 の関係の中で，有意の相関関係が認められたのは TRAb と甲状腺体積との間においてであり， $\mathrm{TRAb}$ と血中 $\mathrm{Tg}$ 濃度との関係は統計上有意ではなかった。その理由は抢そらく TRAbの影響 は, 甲状腺体積に対しては直接的であるが，血中 $\mathrm{Tg}$ 濃度にはむしろ間接的であり，腫大した甲 状腺自体の異常が関与している可能性もあろう。

治療中に一時血中 TSH が高值となった例では甲状腺体積と血中 $\mathrm{Tg}$ 濃度がともに上昇したが, これは TSH が甲状腺細胞の増殖に働き6)，その結果として血中 Tg 濃度を増加させたものと考兄 られる ${ }^{35377}$ 。このことから，抗甲状腺剤治療中の患者で，突然甲状腺腫大が増強したり，あるいは 血中 $\mathrm{Tg}$ 濃度が上昇した時は，薬剂過剩投与の可能性があり注意が必要である。 
バセドゥ病寛解，再発といら面から考察すると，一般に甲状腺腫の小さい例では寛解しやすく， 甲状腺が大きい例は難治性である ${ }^{8229}$ 。またバセドウ病のサブタイプと考兄られている $\mathrm{T}_{3}$ 優位型 バセドウ病（ $\mathrm{T}_{3}$ - predominant Graves’ disease）すなわち抗甲状腺剂治療中，血中 $\mathrm{T}_{4}$ 濃度が正 常であるが血中 $\mathrm{T}_{3} / \mathrm{T}_{4}$ ratio が異常高值を示す患者では, 甲状腺が大きい例が多く，また投薬中 止後再発しやすい、30311。これらの事実は，甲状腺の大きさが患者の予後に深く関与していることを 示している。治療前の甲状腺体積のみで分析すると, 腫大が軽度な例でも寛解を得られない例があっ たため，予後を推測するための指標とするのは不適当と思われる。次に内服治療開始後の体積の変 化に注目すると，治療後1年目の減少率において寛解群と非寛解群との間に有意な差が認められた。 このことから，治療前と治療開始後 1 年目の甲状腺体積を超音波を用いて測定することによって， 治療中止時期を判定するために有用な指標が得られるものと考えた。ただし，薬剂過剩投与によっ て血中 TSH 值を上昇せしめ, 甲状腺腫が増大することは避けるべきであろう。機能低下をきた した4例を除いた16例について分析すると, 未治療時の体積が $60 \mathrm{ml}$ 未満で, 同時に 1 年目の体積 （\%）が85\%未満に減少している例 8 例はすべて寛解した。一方，未治療時 $60 \mathrm{ml}$ 以上もしくは 1 年 目 $85 \%$ 以上の 8 例の 5ち7例は寛解しなかった。すなわち上記基準にもとづけば，16例中 15 例 (93.8\%) にて甲状腺体積のみで予後の判別が可能であったことになる。今後症例数を増やすこと により，適切な判定基準を定めることが可能となろう。

本研究ではコンピュータを用いた著者ら独自の測定装置によった。甲状腺体積の測定が実施臨床 に㧍いて広く一般化されるためには，さらに簡便で，特殊な装置を必要としない体積測定法の開発 が期待される。

\section{結 語}

バセドゥ病患者に対し，電算機化超音波法を用いて抗甲状腺剤治療中の甲状腺体積を経時的に測 定し,その変動を追跡した。

1）未治療時, 甲状腺体積は血中サイログロブリン濃度および TSH レセプター抗体価と有意の 相関関係にあった。

2）抗甲状腺剂治療中, 甲状腺体積は徐々に減少する例が多かった。

3）治療経過中，一過性機能低下症をきたし血中 TSH が上昇した時，甲状腺体積は増加を示し， 血中サイログロブリン濃度も上昇した。

4）治療経過を通して，甲状腺体積と血中サイログロブリン濃度の変動は平行した。

5）寛解が得られた患者では甲状腺体積の減少率が大きく，治療開始後12か月目の\%減少率におい て非寬解患者と比べ有意差を認めた。

以上の成績から，甲状腺体積の測定がバセドウ病患者の予後の推測に有用な情報を与えることが 示唆された。

稿を終えるにあたり，御校閲いただいた大澤仲昭教授，故茂在敏司教授ならびに直接の御指導を いただいた当教室内分泌代謝研究室長の高松順太博士に深く謝意を表する。甲状腺体積測定法の開 発に御援助いただいた本学放射線科赤木弘昭教授, 隈病院院長郎 寛二博士, 当教室武田京子博士 に深く感謝する。当教室の諸先生のご協力にも謝意を表する。

本論文の要旨は第59回日本内分泌学会学術総会 (仙台市), 第8回国際内分泌学会議 (京都市), 第31回日本内分泌学会甲状腺分科会（長崎市）において発表した。 
文献

1) Adams, D.D. and Purves, H.D. : Abnormal response in the assay of thyrotropin. Proc. Univ. Otago. Med. School Otago, New Zealand, 34: 11-12, 1956.

2）赤木弘昭, 白川恵俊, 石田博文, 九谷 亘, 福田徹夫, 舟木 亮, 西川正孝, 五老健彦, 土子正良：電算機超 音波診断装置について。日本医放会誌，40：598-600，1980.

3) Allen, H.C. and Goodwin, W.E.: The scintilation counter as an instrument for in vivo determination of thyroid weight. Radiology, 58: 68-79, 1952.

4) Bliddal, H., Hegedus, L., Hansen, K., Bech, K., Van Der Gaag, R. and Drexhage, H.A.: The relationship between serum $\mathrm{T}_{3}$ index, thyroid volume, and thyroid stimulating, TSH receptor binding and thyroid growth stimulating antibodies in untreated Graves' disease. Clin. Endocrinol., 27: 75-84, 1987.5 5) Chiovato, L., Hammond, L.J., Hanafusa, T., Pujol-Borrell, R., Doniach, D. and Bottazzo, G.F.: Detection of thyroid growth immunoglobulins (TGI) by $[3 \mathrm{H}]$-thymidine in corporation in cultured rat thyroid follicles. Clin. Endocrinol., 19: $581-590,1983$.

6) DeGroot, L.J., Larsen, P.R., Refetoff, S. and Stanbury, J.B. eds.: Graves' disease: diagnosis and treatment. In "The Thyroid and Its Diseases" p.20-24, p.428, 5th Ed. Wiley Medical, New York, 1984.

7) Drexhage, H.A., Bottazo, G.F., Doniach, D., Bitensky, L. and Chayen, J.: Evidence for thyroid-growth-stimulating immunoglobulins in some goitrous thyroid disease. Lancet, 2: 287-292, 1980.

8) Greer, M.A., Kammer, H. and Bouma, D.J.: Short-term antithyroid drug therapy for the thyrotoxicosis of Graves' disease. N. Engl. J. Med., 297: 173-176, 1977.

9）遠藤勝美，貴田岡正史，町田光司，武部和夫：超音波断層法による 甲状腺体積測定の試み。日超医論文集，40：613-614， 1982 .

10) Hegedus, L., Perrild, H., Poulsen, L.R., Andersen, J.R., Holm, B.H., Schnohr, P., Jensen, G. and Hansen, J.M.: The determination of thyroid volume by ultrasound and its relationship to body weight, age, and sex in normal subjects. J. Clin. Endocrinol. Metab., 56: 260-263, 1983. 11) Hegedus, L., Hansen, J.M. and Karstrup, S.: High incidence of normal thyroid gland volume in patients with Graves' disease. Clin. Endocrinol., 19: 603-607, 1983. 12) Ingbar, H.: The thyroid gland. In "Textbook of Endocrinology" p.754, 7th edition, ed. by Wilson, J.D. and Foster, D.W.; W.B. Saunders, Philadelphia, 1985. モンと臨床, 31: 737-743, 1983.

13）石井 淳：バセドウ病とサイログロブリン。ホル sequential changes in serum th Graves' disease and subacute thyroiditis. Metabolism, 27: 449-460, 1978.

15）和泉元衛, 長瀧重信：血中サイログロブリンと甲状腺疾患。臨床病理，30：126-137，1982. 16) McKenzie, J.M. and Zakarija, M.: LATS in Graves' disease. Recent Prog. Horm. Res., 33：29-57, 1977. 17）三木京子, 高松順太, 伊左治治子, 北沢明人, 名方 潔, 古川恵三，茂在敏司：栄研サイログロブリン RIA kitによる血清サイログロブリン濃度測定とその 臨床応用。医学々薬学, 10：1329-1334, 1983. 18）三木京子：電算機化超音波法によ る甲状腺体積測定法の開発とその臨床応用。日内分泌会誌，62：97-107, 1986. 
19）三木京子, 高松順太, 坂根貞樹, 馬嶋素子, 北岡治子, 北沢明人, 片山正一, 森田新二, 小林 彰, 松塚文夫, 隅 寛二: $\mathrm{T}_{3}$ 優位型バセドゥ病の形態学的特徵について。日内分泌会誌, 63: 184-192, 1987.

20) Miki, K., Takamatsu, J., Sakane, S., Majima, M., Kitaoka, H., Akagi, H., Kobayashi, A., Matsuzuka, F., Kuma, K. and Mozai, T.: Determination of thyroid gland volume by a newly developed ultrasonic technique. In "Recent Progress in Thyroidology" p.459-463, ed. by Vihayanrat, A., Nitiyanant, W., Eastman, C. and Nagataki, S.: Crystal House Press, Bangkok, 1987.

21) Olbricht, T., Schmitka, T., Mellinghoff, U., Benker, G. und Remwein, D.: Sonographische Bestimmung von Schilddrusenvolumia bei Schilddrusengesunden. Desch. Med. Wschr., 108: 1355-1358, 1983.

22) Pezzino, V., Vigneri, R., Squatrito, S., Filetti, S., Camus, M. and Polosa, P.: Increased serum thyroglobulin levels in patients with nontoxic goiter. J. Clin. Endocrinol. Metab., 46: 653-567, 1978.

23) Rasmussen, S.N. and Hjorth, L.: Determination of thyroid volume by ultrasonic scanning. J. Clin. Ultrasound, 2: 143-147, $1974 . \quad 24)$ Rasmussen, U.F., Hegedus, L., Hansen, J.M. and Perrild, H.: Relationship between thyroid volume and serum thyroglobulin during long-term suppression with triiodothyronine in patients with diffuse non-toxic goitre. Acta Endocrinol., 105: 184-189, 1984.

25) Refetoff, S. and Lever, E.G.: The value of serum thyroglobulin measurement in clinical practice. J.A.M.A., 250: 2352-2357, 1983.

26）関本 定：電算機化超音波法の研究：甲状腺 を対象として。日本医放会誌，42：513-528，1982.

27) Shewring, G. and Rees Smith, B.: An improved radioreceptor assay for TSH receptor antibodies. Clin. Endocrinol., 17：407-417，1982. 28）七條小次郎：地方甲状腺。日内分泌会誌，29： 155-188, 1953. 29) Shizume, K., Irie, M., Nagataki, S., Matsuzaki, F., Shishiba, Y., Suematsu, H. and Tsushima, T.: Long-term result of antithyroid drug therapy for Graves' disease: follow up after more than 5 years. Endocrinol. Japon., 17(5): 327-332, 1970. 30) Takamatsu, J., Sugawara, M., Kuma, K., Kobayashi, A., Matsuzuka, F., Mozai, T. and Hershman, J.M.: Ratio of serum triiodothyronine to thyroxine and the prognosis of triiodothyronine-predominant Graves' disease. Ann. Intern. Med., 100: 372-375, $1984 . \quad 31$ ) Takamatsu, J., Kuma, K. and Mozai, T.: Serum triiodothyronine to thyroxine ratio: a newly recognized predictor of the outcome of hyperthyroidism due to Graves' disease. J. Clin. Endocrinol. Metab., 62: 980-983, 1986. 32) Takeda, K., Takamatsu, J., Sakane, S., Ikegami, Y., Majima, M., Kitaoka, H., Akagi, H., Kobayashi, A., Matsuzuka, F., Kuma, K.: Determination of thyroid gland volume by a newly developed ultrasound technique. Bull. Osaka Med. Colle., 34: 1-10, 1988. 33) Tannahill, A.J., Hooper, M.J., England, M., Ferriss, J.B. and Wilson, G.M.: Measurement of thyroid size by ultrasound, palpation and scintigram. Clin. Endocrinol., 8: 483-486, $1978 . \quad 34)$ Uller, R.P. and Van Herle, A.J.: Effect of therapy on serum thyroglobulin levels in patients with Graves' disease. J. Clin. Endocrinol. Metab., 46: 747-755, 1978. 35) Unger, J., Van Heuverswyn, B., 
Decaster, C., Cantraine, F., Mockel, J. and Van Herle, A.: Thyroglobulin and thyroid hormone release after intravenous administration of bovine thyrotropin in man. J. Clin. Endocrinol. Metab., 51: 590-594, $1980 . \quad 36)$ Valente, W.A., Vitte, P., Rotella, C.M., Vanghan, M.M., Aloj, S.M., Grollman, E.F., Ambesi-Impiombato, F.S. and Kohn, L.D.: Antibodies that promote thyroid growth: a distinct population of thyroid-stimulating autoantibodies. N. Engl. J. Med., 309: 1028-1034, 1983.

37) Van Herle, A.J., Vassart, G. and Dumont, J.E.: Control of thyroglobulin synthesis and secretion: second of two parts. N. Engl. J. Med.,301: 307-314, 1979.

38）山崎元宥：甲状腺機能立進症の臨床病理学的研究, 特に 1-Methy-2-mercaptoimidazole の 甲状腺腫組織像に及ぼす影響について。東北医学，60：323-351，1959.

39) Yokoyama, N., Nagayama, Y., Kakezono, F., Kiriyama, T., Morita, S., Ohtakara, S., Okamoto, S., Morimoto, I., Izumi, M., Ishikawa, N., Ito, K. and Nagataki, S.: Determination of the volume of the thyroid gland by a high resolutional ultrasonic scanner. J. Nucl. Med., 27: 1475-1479, 1986.

（受付日：'89. 6.19） 